In its simplest terms, the row is about the relative value of the British currency, sterling, and the West German deutschmark, now the most solid of West European currencies and the lynchpin of the European Monetary System (EMS) by means of which most European Community states (but not Britain) maintain the values of each others' currencies within narrow bands in a kind of regional simulation of the old global system of managed currencies set up at Bretton Woods and abandoned only in 1972. Briefly, Lawson wants to keep the value of sterling more or less where it has been since the collapse of the dollar last November, roughly DM3 to the pound sterling, and has been urging the Bank of England to sell sterling and buy deutschmarks to keep the rate constant. His motives are that he does not wish to see the competitiveness of British industry undermined in Western Europe and that he seems to recognize that Britain must sooner or later join EMS (no later than 1992 if moulding the European Community into a common market is not to be a nonsense).

Thatcher, on the other hand, is more concerned about the inflation rate, which has been marvellously reduced under her administration, but which, at just under 4 per cent a year, is still greater than in West Germany. But she appears also to be offended at the waste of public money involved in buying other people's currencies so as to depress the value of your own when, as she put it the other day, everybody knows that "you cannot buck the market". That proposition is well borne out by the experience of the years since 1972, but as stated overlooks the simple truth that one of the principal immediate causes of the recent strength of sterling is that British interest rates (also managed by the Bank of England, on the instruction of Lawson's Treasury) are higher than elsewhere, in West Germany in particular. The economical way of keeping the pound at DM3 would be to reduce interest rates, but that would allow inflation to increase.

Unsurprisingly, neither Lawson nor the governor of the Bank of England openly acknowledged that there has been a row behind the scenes when they gave evidence to the House of Commons Treasury and Civil Service Committee last week, which has not prevented observers parsing all their sentences in the hope of telling what the portents are. (Most probably, the row has now been patched up.) But it is a great surprise that two able and powerful people should find themselves at odds over such a simple matter in the management of a small industrialized state's economy.

The truth is that the prime minister and Lawson have declared two distinct and different objectives, but have more than two adjustable parameters at their disposal. Interest rates and the managed value of the currency are two of them. Another is the size of the government's budget deficit, which tortuously determines the supply of money in the economy, and which Lawson dealt with proudly in last month's budget by declaring that, for the future, the norm will be a balanced budget although, in the year ahead, the government will actually raise $\$ 2,000$ million more in taxes than it will spend. At the same time, Lawson brought about the biggest simplification of the British tax system ever at a cost of roughly $\$ 4,000$ million, most of that quarried from the extra taxes that would be paid on increased salaries in an increasingly prosperous community. But both the prime minister and Lawson know that spending less on tax reductions would have allowed interest rates to be reduced, thus helping the sterling to keep a constant value relative to the deutschmark without running the risk of inflation. There were, of course, political considerations why they agreed that the adjustability of this adjustable parameter should be mortgaged, but that is another story.

So, too, is the more worrying feature of the British economy represented by the deterioration of the balance of external trade and, worse, the secular decline of the savings ratio (the proportion of all after-tax income not immediately consumed) which has fallen from 14 per cent to just under 6 per cent since 1980-almost as bad as the ratio below 4 per cent in the United States. These two worrying trends are linked-less saving means more spending, much of it on imports. The lesson for the British and other improvident economies such as the United States is that governments should be more diligent in providing people with an incentive to save a more substantial fraction of their incomes. That is how Thatcher and Lawson, or their successors, must hope to patch up their differences. Unfortunately, considerations of that kind are also, for the time being, on the back burner.

\section{Windows copyright?}

\section{An impending copyright suit in the United}

\section{States raises testing questions.}

APPLE Corporation's suit against Microsoft (the software company) and Hewlett-Packard for alleged infringement of copyright on computer software raises interesting questions that, when decided, are bound to have far-reaching consequences. Apple's revival of fortunes with the introduction of the personal computer called Macintosh seems to have depended to a large extent on software innovations, not least a scheme for partitioning the display screen into separate patches called "windows", simultaneously usable for the display of information deriving from different programs. Unsurprisingly, other manufacturers of personal computers have taken up the idea (and even IBM is believed to be about to follow suit). But Apple is hoping to put a stop to that by suing its imitators for having breached its copyright. Apple has not made public the details of its claims, although it has talked about its right to protect the character of its method of presenting information on computer video screens and has said that its rivals' computer presentations "look too much like" its own.

The interest of this issue will turn on the degree to which Apple's suit may be judged a wish to protect by copyright law what is simply an idea, however useful and successful. Apple's sense of outrage at what its imitators are about might have been anticipated by the person who first had the idea of letting light into closed buildings by means of apertures in the walls as well as by the one who, later, thought it would make even better sense to let the light in and keep the cold out by covering the apertures with transparent material of some kind. Neither of these innovations would have been patentable under modern patent laws, although specific ways of manufacturing windows are patentable, and specific designs are subject to copyright protection. This is simply a restatement of the doctrine that ideas as such are not patentable.

That is how it should be. The entire system for protecting innovations would be unworkable if people were able to protect their ambitions to accomplish goals still unattainable. Since Apple is presumably legally well advised, it must therefore be assumed that it is not seeking to protect the notion that there should be separate windows on a computer screen, but merely the particular appearance of its own windows as distinct from those of other people, or even the particular methods by which its software has been designed to produce windows of different shape and appearance. If the software is the crucial issue, recent court decisions will give Apple a good case. If, on the other hand, it is asking that other computer manufacturers should be prevented from imitating the appearance of its own windows, it will have a harder case. It would then be as if Nature, having discovered that some other science journal had adopted its own design and layout, were to rush to the courts for redress. It would probably be wiser to take comfort in the maxim that imitation is the sincerest form of flattery-but to be prepared to sue only those who seek to pass off their imitations as the products they wish to emulate. That is what the law now requires. That is also what it should be. 